\title{
An Alternative Approach in Assessing Visual Comfort Based on Students' Perceptions in Daylit Classrooms in the Tropics
}

\author{
Irnawaty Idrus ${ }^{1, *}$, Ramli Rahim², Baharuddin Hamzah ${ }^{2}$, Nurul Jamala² \\ ${ }^{1}$ Doctoral Student of Department of Architecture, Faculty of Engineering, Hasanuddin University, Indonesia \\ ${ }^{2}$ Laboratory of Building Science and Technology, Department of Architecture, Faculty of Engineering, Hasanuddin University, \\ Indonesia
}

Received July 8, 2020; Revised August 26, 2020; Accepted September 11, 2020

\begin{abstract}
Cite This Paper in the following Citation Styles
(a): [1] Irnawaty Idrus, Ramli Rahim, Baharuddin Hamzah, Nurul Jamala, "An Alternative Approach in Assessing Visual Comfort Based on Students' Perceptions in Daylit Classrooms in the Tropics, "Civil Engineering and Architecture, Vol. 8, No.5, pp. 801 - 813, 2020. DOI: 10.13189/cea.2020.080507.
\end{abstract}

(b): Irnawaty Idrus, Ramli Rahim, Baharuddin Hamzah, Nurul Jamala (2020). An Alternative Approach in Assessing Visual Comfort Based on Students' Perceptions in Daylit Classrooms in the Tropics. Civil Engineering and Architecture, 8(5), 801 - 813. DOI: 10.13189/cea.2020.080507.

Copyright $\odot 2020$ by authors, all rights reserved. Authors agree that this article remains permanently open access under the terms of the Creative Commons Attribution License 4.0 International License

\begin{abstract}
Daylight is the best lighting source for classrooms that are mostly used during the daytime. Effectiveness and productivity can be achieved if visual comfort meets the recommendations set. This study aims to develop an alternative visual comfort assessments method based on students' perceptions in the classroom with daylight. The study was carried out by collecting students' perceptions and daylight illuminance data from 25 classrooms located in seven schools in Makassar, Indonesia. A total of 737 students responded to this study. This research was conducted from morning to noon in each school. The results showed that the majority of students, as many as $57.5 \%$, felt that the level of daylight was "Perceptible", and only $6.5 \%$ felt it was "Intolerable". The results of daylight intensity measurements of 25 classes showed that only $28 \%$ of classes meet the minimum standard of the Indonesian National Standard (SNI), and as many as $82 \%$ of classes do not meet the standard. Using a new method based on student perception, it was concluded that as many as $28 \%$ of classes were categorized as "Acceptable", as many as $48 \%$ of classes were categorized as "Preferred," and around 24\% were not included in either category. This shows that there are classes that are not in accordance with recommendations, but are still acceptable according to students' perceptions. This new assessment method can be an alternative addition for designers to
\end{abstract}

assess the comfort of a room with daylight by users' preferences.

Keywords Visual Comfort, Daylight, Classroom, Students' Perceptions

\section{Introduction}

Many previous studies have explained that natural lighting is the best source of light for buildings because it has many benefits. Natural light helps create a healthy, comfortable, and productive environment $[1,2]$. In addition, the use of significant natural light in buildings has the potential to save $15-19 \%$ of electricity cost for lighting $[3,4]$. Architecturally, natural light is also useful for creating dramatic design elements that provide a deep visual experience [5].

However, natural lighting can only be used optimally if there is enough sunlight in the area [5]. According to Baharuddin and Ishak, Makassar city has great potential for utilizing sunlight [6]. A Research by Rahim et al. showed that, in June 2010, the value of global illuminance measured in Makassar reached 142 kilolux [7, 8]. This could be due to its location in a tropical area. This global 
illuminance is higher than the region located in sub-tropical areas, e.g., Hong Kong, which has a maximum global illuminance of 125 kilolux [8]. The tropical zone extends from latitude $10^{\circ}$ to $23^{\circ}$. Due to its geographical proximity to the equator, it has an annual dry season during all months. The sunshine in the tropics is available all year round. Subtropics extend a further $10^{\circ}$ towards higher latitudes to about $35^{\circ}$ North and South, and, in these areas, the dry winters extend to about eight months of the year [9]. Natural lighting is highly recommended for educational buildings [10]. Over the years, natural lighting has been one of the most important factors in school design rather than in other building designs [11]. Some researchers have suggested the positive impact of natural lighting on user performance [12], creating a pleasant environment [13], creating a healthy environment [14], and supporting the creation of sustainable building designs [15].

The fact that students spend as much as $30 \%$ of their time studying at school is a reason for the importance of visual comfort in a school building [16]. Sunlight can have both positive and negative effects on visual comfort because of its dynamic nature. It has an important role in creating comfort in space [17]. Daylight can also affect performance in reading and completing assignments, and it can also affect the students' moods, emotions, and behavior [18].

Visual comfort is influenced by various interrelated factors. Existing metrics only evaluate one variable at a time; therefore, no index has been defined which can be considered as a parameter to represent the visual environment. To compare buildings or building variants, a percentage index is usually preferred, because it does not depend on the absolute magnitude of the phenomenon involved. In addition, individual values allow for easier data comparison and interpretation, and more effective interpretation of results [19].

This paper discusses visual assessment of comfort in classrooms based on students' perceptions. In this study, the authors aim to develop dynamic metrics based on user perceptions to assess students' visual comfort by asking several questions that refer to Spatial Daylight Autonomy (sDA) and Annual Sunlight Exposure (ASE). The questions will illustrate several factors that influence visual comfort, such as the amount of light, uniformity of light, quality of light, and glare according to students' perceptions. The method is an alternative approach in assessing visual comfort in classroom during daylight. A more comforting environment will support student performance in learning. Learning environment is an essential key factor in determining the academic achievement of students [20].

\section{Literature Review}

Many researchers around the world initially assess visual discomfort based on the level of glare, independent of personal preferences. Guth, who introduced the Glare Index in 1949 [21] and others compiled a visual discomfort assessment formula by predicting the level of glare. In 1972, Hopkinson formulated The Daylight Glare Index (DGI or Cornell Equation) [22]. This was followed by introduction of the CIE Glare Index (CGI) by Einhorn in 1979 [23]. This CGI was later refined by the Commission Internationale de l'Eclairage in 1995 with the formulation of The Unified Glare Rating System (UGR) [24]. In 2001, Nazzal developed the New Daylight Glare Index (DGIN), which is a modification of Hopkinson's original equation that introduces several new variables into the metric [25]. All of these methods show correlations between light sources and potential glare, but glare is a complex phenomenon, and the assessment of glare will be different for each observer.

After a few years, methods to assess glare were enchanced to include user glare preferences. Harrold and others proposed the concepts and formulas of Visual Comfort Probability (VCP) [26]; Wienold \& Christoffersen [27] developed Daylight Glare Probability (DGP) calculated by glare in vertical illumination. Hirning [28] validated previous glare measurements and introduced the Unified Glare Probability (UGP) as a predictor of glare discomfort, by using a combination of natural lighting mapping and user questionnaires [29]. Several studies on visual comfort involving user questionnaires have been conducted, such as by Chinazzo, which concluded that no significant differences in evaluation of visual perception were found between the moderate and high levels of daylight, especially in terms of visual comfort [30]. Korsavi's research determined that daylight and sunlight areas are no necessarily based on students' perceptions, and concluded that these areas do not always cause visual discomfort [31]. Methods involving user preferences will certainly show a strong correlation with the perception of glare, but glare is not the only factor that can cause visual discomfort in daylighting spaces. Several metrics related to natural lighting should be examined to find new, more complex approaches to visual comfort.

Some important aspects that are considered in natural lighting include the amount of daylight, personal satisfaction, and energy conservation. To assess various aspects of the day, experts use primarily dynamic as opposed to static metrics [32]. Several studies have revealed the advantages of dynamic metrics compared to static metrics [33, 34]. Dynamic metrics take into account daily and seasonal changes in natural lighting [35], which static metrics do not consider. Static metrics also do not account for user convenience [36]. Therefore, dynamic metrics are also referred to as climate-based metrics [36]. Climate-Based Daylight Modeling (CBDM) is a new approach approved by IES for daytime evaluation, based on two metrics based on daytime conditions of a typical meteorological year (TMY): Spatial Daylight Autonomy (sDA) and Annual Sunlight Exposure (ASE) (IES LM 83-12) [37]. Spatial Daylight Autonomy (sDA) measures 
the adequacy of daylighting for a particular area; this is defined as the percentage of floor area, which meets or exceeds the specified lighting level (300 lux recommended on a horizontal surface, $0.8 \mathrm{~m}$ above the finished floor) for a certain number of annual hours (recommendation: $50 \%$ of hours from 8 am to $6 \mathrm{pm}$ ). IES recommends two different levels of quality for Spatial Daylight Autonomy; if $75 \%$ or more of the analysis area meets the criteria categorized as "Preferred", and if 55\% or more of the analysis area meets the criteria categorized as "Acceptable" [38]. Spatial Daylight Autonomy is a comprehensive performance metric combining time and space, which can be more easily understood. Annual Sunlight Exposure (ASE) assesses the potential for visual discomfort caused by direct sunlight in the work area (lighting value indicator > $=1000$ lux). ASE is defined as a percentage of the analysis area that exceeds 1000 lux for more than 250 hours per year without using blinds and assuming operational time between 8a.m. to 6p.m. [39, 40]. All of the aforementioned metrics and assessment methods have their respective advantages and disadvantages. Fundamentally, all of these visual comfort metrics can complement each other. Previous assessment methods formulated by researchers have not included user perception as a measure of visual comfort. Based on this, an alternative approach to assessing visual comfort based on user perceptions could further complement existing assessment methods.

\section{Materials and Methods}

\subsection{Methodological Framework}

The methodology essentially includes three stages. In the first stage, the object of research is the level of natural lighting in classrooms. Data was collected using measurement tools, and then analyzed for suitability with the classroom minimum lighting rules defined by the Indonesian National Standard (SNI). At this stage, supporting data is collected, such as the geometry of the classroom, the size of light openings, the orientation of the class, weather conditions, and the situations around the research object.

In the second stage, the object of research is the perception of students' visual comfort in a classroom with natural lighting. Data collection for the first and second stages was carried out simultaneously. Student perception data was obtained using a questionnaire. The questionnaire contained the respondent's information, date and time of measurement, sitting position, class orientation, sky condition, and questions regarding visual comfort perception. Respondents answered each number according to the instructions of the researcher. Before students answered questions, researchers first provided an understanding of the purpose of the questions to be answered, so students would understand the purpose of the question. Technical terms such as "overall sensation of visual comfort" and "glare" are explained to students in easy-to-understand language. In addition, to help researchers achieve the research objectives, the selected respondents were of age ten years and over.

Student perception is measured through a questionnaire consisting of four questions. The student questionnaire uses a Likert scale, which consists of five answer choices. The first and second questions are 'students' impressions about daylight availability and uniformity (sDA-related questions), and the third and fourth questions are 'students' impressions about sunlight (ASE-related questions) [31]. Both of these metrics are dynamic metrics, that are also referred to as Climate-Based Daylight Modeling (CBDM). The first question asks about perception of the availability of daylight (DA) at the student's desk. The question showed students' perceptions about the adequacy of light perceived in their respective places. The second question asks about the perception of daylight uniformity (DU) throughout the classroom, showing students' perceptions of the adequacy of light felt throughout the classroom. The third question about Sunlight Comfort (SC) asks about students' opinions of direct sunlight entering the class. The fourth question about Perception of Glare (GP), asks about students' perceptions of the glare felt in the classroom. Students chose their answers according to their feelings about the daylight condition. The last question asks about conclusions about the overall sensation of visual comfort felt. The answers from students also indicated the percentage of perceived daylight comfort in class. The data was analyzed using the descriptive analysis method.

In the third stage, the object of research is the visual comfort of the classroom. At this stage, the classroom is assessed using the proposed method. The data that has been obtained in the second stage is reanalyzed by this method. Before determining the variables used to assess the visual comfort of the classroom, Pearson's bivariate correlation statistics are held first on the Questionnaire Question. The proposed assessment formula is adopted from the Spatial Daylight Autonomy (sDA) metric.

\subsection{Research Location and Respondents}

There are 25 classes in the research sample, located in seven schools consisting of elementary, junior, and senior high schools in Makassar City, Indonesia. The object of research is public schools owned by the government. Government-owned schools were chosen because they have similar classroom dimensions, but differ in the openness model and size. Three to five classes are chosen for each school to be the object of research, with North-South and East-West orientations. Details of the research object can be seen in Table 1 .

The assessment data was obtained from a questionnaire filled out by students. A total of 737 students responded to this study. In elementary school, only classes that are 
occupied by students in the year of four, five, or six are selected. For junior high schools, classes are selected for all levels, and also for senior high schools. The age of respondents ranges from 10 to 16 years old. All participants had a normal or correct-to-normal vision. Details of the respondents are presented in Table 2.

\subsection{Data Collection Method}

Data on daylight comfort perception was obtained through a questionnaire that was distributed to students. Data was collected in the classroom for 30 to 49 minutes in each class. This research was conducted from morning until noon. During the study, all the curtains were opened and only natural light was used as a source of classroom lighting. All electric lights were turned off. Students answer the questionnaire from their numbered position. The pattern of numbering student positions can be seen in Figure 1(a). While filling out the questionnaire, the light intensity data was taken using the Digital Lux Meter and HOBO Data Logger measurement tools; the HOBO device is equipped with an external sensor which can function to measure temperature, light intensity, and humidity [41]. In addition, measurements of the classroom's dimensions include the length, width, and height of the classroom using Krisbow digital distance meters. The opening's dimensions measurement are carried out using a manual distance meter. The placement of the measuring instrument and the measuring point can be seen in Figure 1(b). Placement of measuring points is regulated based on SNI 03-2396-2001, consisting of two main measuring points (TUU-1 and TUU-2) and four side measuring points (TUS-1, TUS-2, TUS-3, and TUS-4). The location of the TUU is $1 / 3 \mathrm{~d}$ (from the field of the effective light wall), and TUS is 0.5 meters from the side wall [42]. The specifications of the measurement tools can be seen in Table 3 .

Table 1. Characteristic of Classrooms

\begin{tabular}{|c|c|c|c|c|c|}
\hline Grade & School Name & $\begin{array}{l}\text { Class } \\
\text { Code } \\
\end{array}$ & $\begin{array}{c}\text { Room Dimension (length } \mathrm{x} \\
\text { width } \mathrm{x} \text { height in } \mathrm{m} \text { ) }\end{array}$ & Opening dimension $\left(\mathrm{m}^{2}\right)$ & Opening Orientation \\
\hline \multirow{7}{*}{$\begin{array}{l}\text { Elementary } \\
\text { School }\end{array}$} & \multirow{3}{*}{$\begin{array}{c}\text { SD Ujung } \\
\text { Pandang Baru } 1\end{array}$} & 1 & $7.5 \times 7 \times 3$ & 12.66 & $\mathrm{E} / \mathrm{W}$ \\
\hline & & 2 & $7.5 \times 7 \times 3$ & 12.66 & $\mathrm{E} / \mathrm{W}$ \\
\hline & & 3 & $7.5 \times 7 \times 3$ & 12.66 & $\mathrm{E} / \mathrm{W}$ \\
\hline & \multirow{4}{*}{ SD Daya 1} & 22 & $7.5 \times 7 \times 2.8$ & 12.52 & E/W \\
\hline & & 23 & $7.5 \times 7 \times 2.8$ & 12.52 & E/W \\
\hline & & 24 & $7.5 \times 7 \times 2.8$ & 12.52 & $\mathrm{E} / \mathrm{W}$ \\
\hline & & 25 & $7.5 \times 7 \times 2.8$ & 12.52 & E/W \\
\hline \multirow{7}{*}{$\begin{array}{l}\text { Junior High } \\
\text { School }\end{array}$} & \multirow{4}{*}{ SMPN 29} & 9 & $9 \times 7 \times 3.3$ & 24.08 & $\mathrm{~N} / \mathrm{S}$ \\
\hline & & 10 & $9 \times 7 \times 3.3$ & 28.28 & $\mathrm{~N} / \mathrm{S}$ \\
\hline & & 11 & $9 \times 7 \times 3.3$ & 18.2 & $\mathrm{~N} / \mathrm{S}$ \\
\hline & & 12 & $9 \times 7 \times 3.3$ & 24.08 & $\mathrm{~N} / \mathrm{S}$ \\
\hline & \multirow{3}{*}{ SMPN 10} & 19 & $9 \times 7 \times 3.3$ & 28.7 & $\mathrm{~N} / \mathrm{S}$ \\
\hline & & 20 & $9 \times 7 \times 3.3$ & 10.32 & $\mathrm{~N} / \mathrm{S}$ \\
\hline & & 21 & $9 \times 7 \times 3.3$ & 28.7 & $\mathrm{~N} / \mathrm{S}$ \\
\hline \multirow{11}{*}{$\begin{array}{l}\text { Senior High } \\
\text { School }\end{array}$} & \multirow{5}{*}{ SMAN 4} & 4 & $9 \times 8 \times 3.8$ & 23.52 & E/W \\
\hline & & 5 & $9 \times 8 \times 3.8$ & 18.9 & E/W \\
\hline & & 6 & $9 \times 8 \times 3.8$ & 13.3 & $\mathrm{E} / \mathrm{W}$ \\
\hline & & 7 & $9 \times 8 \times 3.8$ & 14.28 & E/W \\
\hline & & 8 & $9 \times 8 \times 3.8$ & 16.8 & E/W \\
\hline & \multirow{3}{*}{ SMAN 2} & 13 & $9 \times 8 \times 3.0$ & 19.6 & $\mathrm{~N} / \mathrm{S}$ \\
\hline & & 14 & $9 \times 8 \times 3.0$ & 19.6 & $E / W$ \\
\hline & & 15 & $9 \times 8 \times 3.0$ & 19.6 & E/W \\
\hline & \multirow{3}{*}{ SMAN 21} & 16 & $9 \times 8 \times 3.7$ & 21.63 & $\mathrm{E} / \mathrm{W}$ \\
\hline & & 17 & $9 \times 8 \times 3.7$ & 21.63 & $\mathrm{~N} / \mathrm{S}$ \\
\hline & & 18 & $9 \times 8 \times 3.7$ & 21.63 & $\mathrm{~N} / \mathrm{S}$ \\
\hline
\end{tabular}

Table 2. Characteristic of Respondent

\begin{tabular}{|c|c|c|c|c|}
\hline School & Boy & Girl & Age (Year) & Total \\
\hline Elementary & 89 & 99 & $10-13$ & 188 \\
\hline Junior High School & 94 & 130 & $12-14$ & 224 \\
\hline Senior High School & 129 & 196 & $14-16$ & 325 \\
\hline Total & 312 & 425 & - & 737 \\
\hline
\end{tabular}


Table 3. Specification of Measurement Tools

\begin{tabular}{|c|c|c|c|c|}
\hline No. & Instrumen Name & Range & Accuracy & Resolution \\
\hline 1 & $\begin{array}{c}\text { HOBO Data Logger Temp/RH/Light/External } \\
\text { (U12-012) }\end{array}$ & & & \\
\hline & - Air Temperature & -20 to $+70 \mathrm{oC}$ & $\pm 0.21 \mathrm{oC}$ & $0.03 \mathrm{oC}$ at $25 \mathrm{oC}$ \\
\hline & - Relative Humidity & 5 to $95 \%$ & $\pm 2.5 \%$ & $0.03 \mathrm{RH}$ \\
\hline 2 & - Lighting Intensity & $11-32292 \mathrm{Lux}$ & NA (indoor use) & NA (indoor use) \\
\hline & Digital Lux Meter & & & 0.1 Lux \\
\hline 3 & - Lighting Intensity & $0.1-200000 \mathrm{Lux}$ & $\pm 4 \%$ & NA \\
\hline
\end{tabular}

NA $=$ Not Available

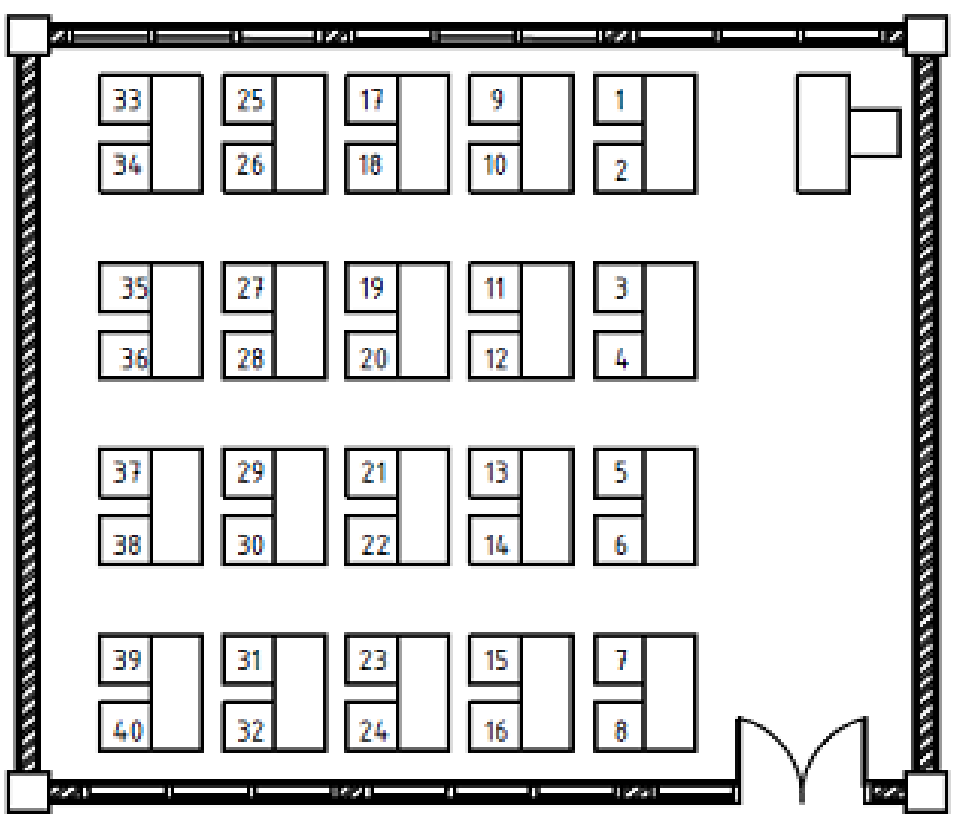

(a)

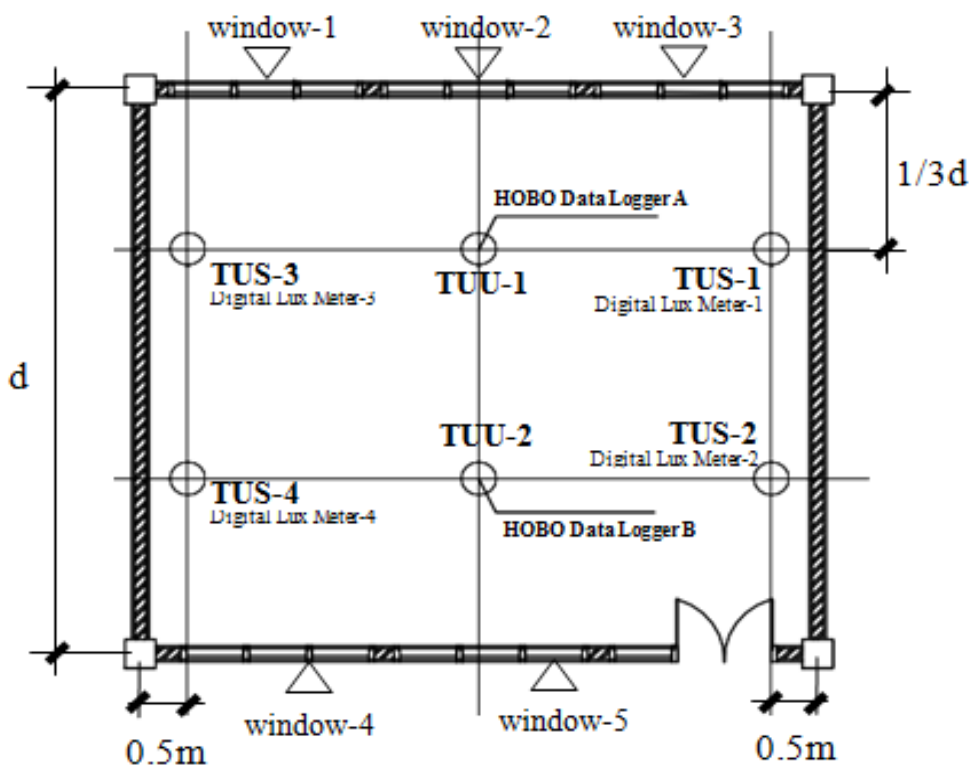

(b)

Figure 1. (a) Numbering of Student Position; (b) The Measurement Point 


\subsection{Data Analysis Method}

The data obtained were analyzed using SPSS statistical software and Microsoft Excel. Data analysis was carried out in several stages, including:

\subsubsection{Data Entry}

All data obtained in the field is inputted into SPSS. The variables are the student's name, age, gender, eye conditions, weather conditions, date, time, school name, grades, sitting positions, daylight intensity, opening area, DA perception, DU perception, SC perception, GP perception and also the classroom orientation. According to Jamala, the orientation variable affects the distribution of sunlight [43].

\subsubsection{Descriptive Statistical Analyses}

Student perception data is grouped by each class.. Descriptive statistical analysis was performed on the variables of DA perception, DU perception, SC perception, and GP perception using SPSS. The visual comfort value of students generated in five levels of perception, namely Intolerable (I), Disturbing (D), Perceptible (P), Comfortable (Cf), and Very Comfortable (VCf). The student's comfort value is presented as a percentage.

\subsubsection{Analyses of Students' Perception}

The student comfort value is included in a table in Excel format, like the example in Table 5. After inputting the data in the table, the results obtained, which shows the percentage of students' visual comfort perception in a classroom.

\subsubsection{Assessing the Daylight Comfort of Classroom}

To assess the visual comfort of daylight in the classroom, an assessment method was used based on student preferences. Before determining the factors that most influence visual comfort, a statistical correlation analysis is performed. Students' questionnaire answers were analyzed using an assessment method called Probability of Daylight Comfort (i-DCP). This method was adapted from the Spatial Daylight Availability (sDA) assessment. IES recommends two different levels of quality for Spatial Daylight Autonomy, and the first is if $75 \%$ or more of the analysis area meets the criteria categorized as "Preferred", the second is if 55\% or more of the analysis area meets the criteria categorized as "Acceptable".

This method assessed a room based on user preferences of whether its daylight comfort is "Acceptable" or "Preferred". Assessment results in two-tailed categories.

1st Category: "ACCEPTABLE" if $(\mathrm{P}+\mathrm{Cf}+\mathrm{VCf})>=55 \%$

2nd Category: "PREFERRED" if: $(\mathrm{P}+\mathrm{Cf}+\mathrm{VCf})>=75 \%$

$\begin{array}{ll}\text { Abbreviation note. } \\ \text { sDA } & \text { : Spatial Daylight Autonomy } \\ \text { ASE } & \text { : Annual Sunlight Exposure } \\ \text { DA } & \text { : Daylight Availability on Desk } \\ \text { DU } & \text { : Overall Daylight Uniformity } \\ \text { SC } & \text { : Sunlight Comfort } \\ \text { CBDM } & \text { : Climate Based Daylight Modelling } \\ \text { GP } & \text { : Perception of Glare } \\ \text { I } & \text { : Intolerable } \\ \text { D } & \text { : Disturbing } \\ \text { P } & \text { : Perceptible } \\ \text { Cf } & \text { : Comfortable } \\ \text { VCf } & \text { : Very Comfortable }\end{array}$

\section{Results}

\subsection{Daylight Intensity of Classrooms}

Data collection was conducted from July to August 2019. The weather conditions were mostly sunny at the time of data collection. The light intensity data is analyzed for compliance with the minimum lighting rules by the Indonesian National Standard (SNI). Descriptive analysis was carried out; the average value of light intensity was compared to its compliance with SNI rules. The minimum average light intensity value must be above or equal to 250 Lux. Based on these rules, the results obtained that only seven of the 25 classes that meet the SNI standard and as many as 18 classes do not. The data on the results of measuring natural light intensity can be seen in Table 12 .

\subsection{Student's Visual Comfort Perception}

Data collection is carried out simultaneously with daylight intensity data collection. After analyzing the perception data of 737 respondents, the results show that an averages 3\% felt "very comfortable", and $12.5 \%$ felt "comfortable". The highest percentage of respondents who felt that the level of natural light in the class was "perceptible" 57.5\%. "Perceptible" means that the respondent is less comfortable, but still perceives that there is enough light to work well and they are not constrained. The percentage of students who felt that the level of natural light was "disturbing" was also quite large, at $20.5 \%$. "Disturbing" means students already feel uncomfortable and a little disturbed, but are still able to work. The percentage of students who felt "intolerable" is 6.5\%. "Intolerable" means students already feel uncomfortable and find it difficult to work well. Based on a direct interview between the author and the respondent, when experiencing this, students overcome it by moving into a

(2itting position or turning on an electric lamp when they

(2) feel uncomfortable. The graphs of students' visual comfort sensations are presented in Figure 2 and Figure 3. 


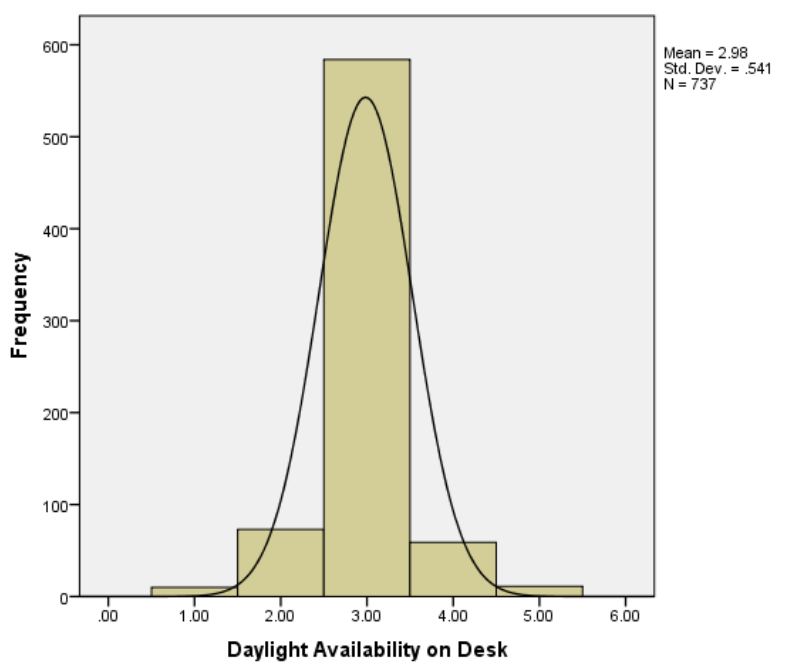

(a)

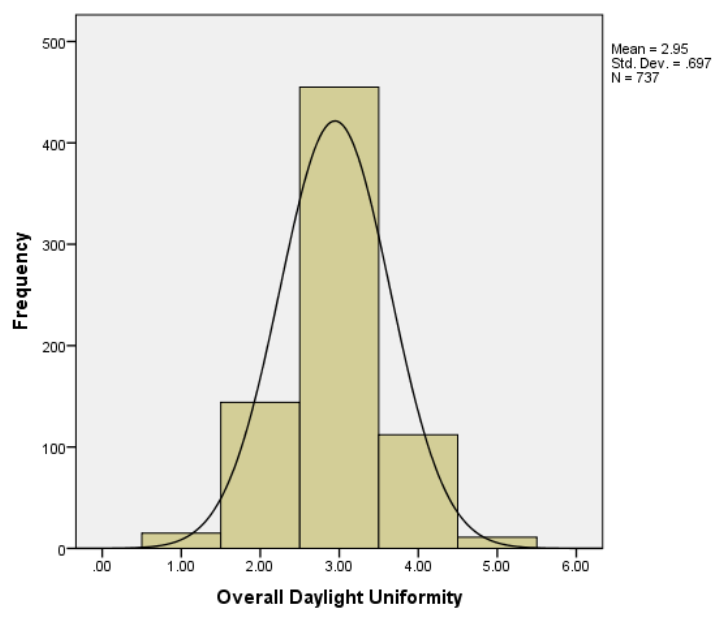

(b)

Figure 2. (a) Daylight Availability on Desks (DA) Perception Chart; (b) Overall Daylight Uniformity (DU) Perception Chart

From Figure 2(a), it can be seen that the majority of students who gave "Perceptible" responses to the questionnaire regarding Daylight Availability on Desks felt that the daylight availability is within normal limits and does not interfere with their activities. From the curve on the histogram chart, the spread of the data looks normal.

From Figure 2(b), it can be seen that the majority of students who gave "Perceptible" responses to the questionnaire regarding Overall Daylight Uniformity felt that the availability of light in the whole class is within normal limits, is even, and does not interfere with their activities. From the curve on the histogram chart, the spread of the data looks normal.

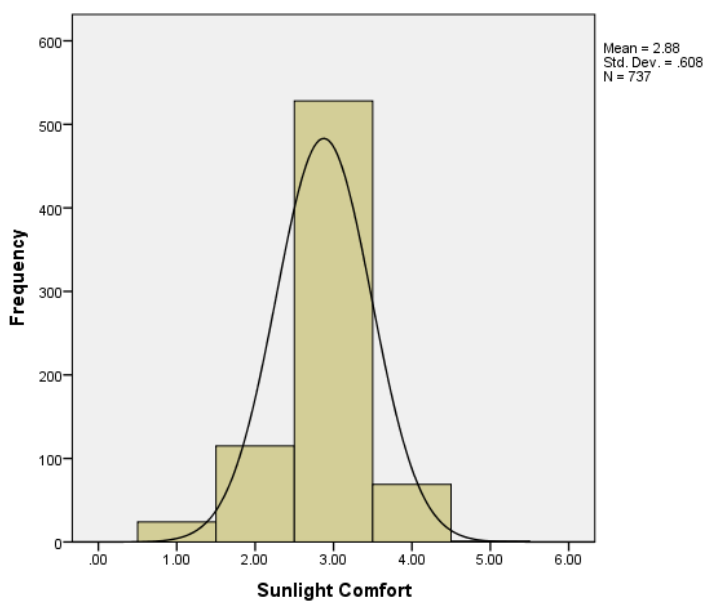

(a)

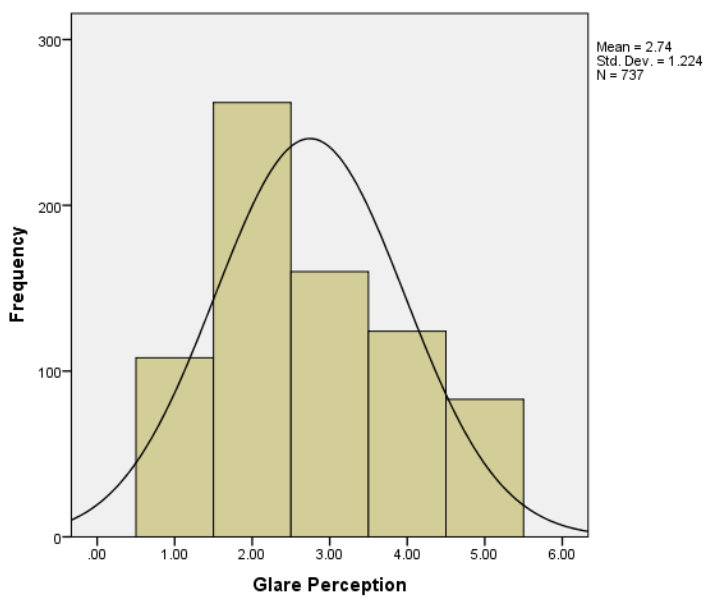

(b)

Figure 3. (a) Sunlight Comfort (SC) Perception Chart; (b) Glare Perception (GP) Perception Chart

From Figure 3(a), it can be seen that the majority of students who gave "Perceptible" responses to the questionnaire regarding Sunlight Comfort felt that sunlight exposure in the classroom was still within normal limits and did not cause visual discomfort. From the curve on the histogram chart, the spread of the data looks normal.

From Figure 3(b), it can be seen that the majority of students who gave "Disturbed" responses to the questionnaire regarding Glare Perception felt disturbed by the glare that occurs in the classroom, but even though they feel disturbed, they can still tolerate this situation. When they feel the glare, the students moved into a sitting position to find a comfortable position. From the curve on the histogram chart, the data distribution is still in the normal category. 
From all these results, it can be seen that the percentage of students who feel "Perceptible Comfort" is quite high, at $57.5 \%$. "Perceptible" means that the respondent is not comfortable, but also does not feel disturbed by the natural lighting in the classroom. Respondents felt normal, even though the light intensity was at a number below the recommended standard. The minimum value of light intensity in the classroom according to SNI is 250 Lux [42]. According to Idrus, in several schools in Makassar, only $25 \%$ met the SNI standards and $75 \%$ of the classrooms did not meet them [44].

\subsection{Assessing Daylight Comfort Probability (i-DCP) of Classrooms}

Before determining the variables that were used to assess the visual comfort of the classroom, Pearson's bivariate correlation statistics are held first on the Questionnaire Question. Overall, Daylight Uniformity (DU), Glare Perception (GP), and Sunlight Comfort (SC) criteria have a significant correlation with perceptions of overall visual comfort. Correlation analysis of variables were performed.

Daylight Availability on Desk (DA) does not seem to have a strong correlation. As can be seen in Table 5, the significance value of the three variables DU, SC, GP, are sig $<0.05$, and the significance value of DA is sig $>0.05$. In addition, asterisks also indicate the level of significance.

Daylight Comfort Probability assessment based on students' perceptions has been carried out in 25 classes. Six cases are presented in this paper; two cases representing ratings that are categorized as "Preferred", two cases represent the category "Acceptable", and two cases that represent the category "Not Acceptable/ Preferred". Daylight Comfort Probability of Classroom assessment that is categorized as "Preferred" is presented in Table 6 and Table 7 along with the discussion. The Daylight Comfort Probability assessment that is categorized as "Acceptable" is presented in Table 8 and Table 9 along with the discussion. Furthermore, the Daylight Comfort Probability assessment that is categorized as "Not Acceptable" is presented in Table 10 and Table 11 along with the discussion.

Table 4. Results of Statistic Analysis of Student's Visual Comfort (All Cases)

\begin{tabular}{|c|c|c|c|c|c|c|c|}
\hline \multicolumn{2}{|c|}{ CBDM } & Intolerable & Disturbing & Perceptible & Comfortable & Very Comfortable & $\operatorname{Sum}(\%)$ \\
\hline \multirow[t]{2}{*}{ sDA } & DA & 1.4 & 9.6 & 79.3 & 8.3 & 1.3 & 100.0 \\
\hline & DU & 3.2 & 18.3 & 60.9 & 15.9 & 1.8 & 100.0 \\
\hline \multirow[t]{2}{*}{ ASE } & $\mathrm{SC}$ & 5.3 & 18.2 & 67.2 & 9.2 & 0.1 & 100.0 \\
\hline & GP & 15.9 & 35.9 & 22.5 & 16.8 & 8.9 & 100.0 \\
\hline \multicolumn{2}{|c|}{ Average (\%) } & 6.5 & 20.5 & 57.5 & 12.5 & 3.0 & 100.0 \\
\hline
\end{tabular}

Table 5. Results of Statistic Analysis of Student's Visual Comfort (All Cases)

Correlations

\begin{tabular}{|c|c|c|c|c|c|c|}
\hline & & $\begin{array}{c}\text { Overall Visual } \\
\text { Comfort } \\
\end{array}$ & DA & DU & GP & SC \\
\hline \multirow{3}{*}{ Overall Visual Comfort } & Pearson Correlation & 1 & .057 & $.116^{* *}$ & $.269^{* * *}$ & $.186^{* *}$ \\
\hline & Sig. (2-tailed) & & .123 & .002 & .000 & .000 \\
\hline & $\mathrm{N}$ & 737 & 737 & 737 & 737 & 737 \\
\hline \multirow{3}{*}{$\begin{array}{c}\text { Daylight Availability on } \\
\text { Desk (DA) }\end{array}$} & Pearson Correlation & .057 & 1 & $.257^{* *}$ & $.097^{* *}$ & -.066 \\
\hline & Sig. (2-tailed) & .123 & & .000 & .008 & .074 \\
\hline & $\mathrm{N}$ & 737 & 737 & 737 & 737 & 737 \\
\hline \multirow{3}{*}{$\begin{array}{l}\text { Overall Daylight } \\
\text { Uniformity (DU) }\end{array}$} & Pearson Correlation & $.116^{* *}$ & $.257^{* *}$ & 1 & $.096^{* *}$ & $-.101^{* *}$ \\
\hline & Sig. (2-tailed) & .002 & .000 & & .009 & .006 \\
\hline & $\mathrm{N}$ & 737 & 737 & 737 & 737 & 737 \\
\hline \multirow{3}{*}{ Glare perception (GP) } & Pearson Correlation & $.186^{* *}$ & -.066 & $-.101^{* *}$ & $.109^{* *}$ & 1 \\
\hline & Sig. (2-tailed) & .000 & .074 & .006 & .003 & \\
\hline & $\mathrm{N}$ & 737 & 737 & 737 & 737 & 737 \\
\hline \multirow{3}{*}{ Sunlight comfort (SC) } & Pearson Correlation & $.269^{* *}$ & $.097^{* *}$ & $.096^{* *}$ & 1 & $.109^{* *}$ \\
\hline & Sig. (2-tailed) & .000 & .008 & .009 & & .003 \\
\hline & $\mathrm{N}$ & 737 & 737 & 737 & 737 & 737 \\
\hline
\end{tabular}

*. Correlation is significant at the 0.05 level (2-tailed)

**. Correlation is significant at the 0.01 level (2-tailed). 
Table 6. Statistical Analysis of Student Visual Comfort Data in the Classroom (Case-1)

\begin{tabular}{|c|c|c|c|c|c|c|c|c|c|c|c|}
\hline & \multirow{2}{*}{$\begin{array}{l}\text { Classroom } \\
\text { Code }\end{array}$} & \multicolumn{3}{|c|}{ Daylight Intensity (Lux) } & \multirow{2}{*}{ Orientation } & I & \multirow[t]{2}{*}{$\mathrm{D}$} & \multirow[t]{2}{*}{$\mathrm{P}$} & \multirow{2}{*}{$\frac{\mathrm{Cf}}{4}$} & \multirow{2}{*}{$\frac{\mathrm{VCf}}{5}$} & \multirow{2}{*}{$\begin{array}{l}\text { Sum } \\
(\%)\end{array}$} \\
\hline & & $\min$ & $\max$ & mean & & 1 & & & & & \\
\hline DU & \multirow{3}{*}{ UP-I } & \multirow{3}{*}{113} & \multirow{3}{*}{371} & \multirow{3}{*}{261} & \multirow{3}{*}{$\mathrm{E} / \mathrm{W}$} & 0 & 16 & 80 & 4 & 0 & 100 \\
\hline $\mathrm{SC}$ & & & & & & 4 & 12 & 80 & 4 & 0 & 100 \\
\hline GP & & & & & & 4 & 24 & 0 & 0 & 72 & 100 \\
\hline \multicolumn{6}{|c|}{ Average (\%) } & 2.7 & 17.3 & 53.3 & 2.7 & 24.0 & 100 \\
\hline
\end{tabular}

Based on the data in Table 6, the assessment Daylight Comfort of Classroom (Case-1) is:

- $\mathrm{P}=53.3 \% ; \mathrm{Cf}=2.7 \% ; \mathrm{VCf}=24 \%$; then $(\mathrm{P}+\mathrm{Cf}+\mathrm{VCf})=80 \%$

- $\quad$ Referring to Eq. (2), the result of Daylight Comfort Probability (i-DCP) in Case-1 is "PREFERRED".

Table 7. Statistical Analysis of Student Visual Comfort Data in the Classroom (Case-2)

\begin{tabular}{|c|c|c|c|c|c|c|c|c|c|c|c|}
\hline & \multirow{2}{*}{$\begin{array}{l}\text { Classroom } \\
\text { Code }\end{array}$} & \multicolumn{3}{|c|}{ Daylight Intensity (Lux) } & \multirow{2}{*}{ Orientation } & I & \multirow{2}{*}{$\frac{\mathrm{D}}{2}$} & \multirow{2}{*}{$\frac{P}{3}$} & \multirow{2}{*}{$\frac{\mathrm{Cf}}{4}$} & \multirow{2}{*}{$\frac{\mathrm{VCf}}{5}$} & \multirow{2}{*}{$\begin{array}{c}\text { Sum } \\
(\%)\end{array}$} \\
\hline & & $\min$ & $\max$ & mean & & 1 & & & & & \\
\hline DU & \multirow{3}{*}{$29-\mathrm{I}$} & \multirow{3}{*}{136} & \multirow{3}{*}{150} & \multirow{3}{*}{143} & \multirow{3}{*}{$\mathrm{N} / \mathrm{S}$} & 0 & 10 & 86.7 & 3.3 & 0 & 100 \\
\hline SC & & & & & & 0 & 10 & 73.3 & 13.4 & 3.3 & 100 \\
\hline GP & & & & & & 23.3 & 20 & 23.3 & 10 & 23.4 & 100 \\
\hline \multicolumn{6}{|c|}{ Average (\%) } & 7.8 & 13.3 & 61.1 & 8.9 & 8.9 & 100 \\
\hline
\end{tabular}

Based on the data in Table 6, the assessment Daylight Comfort of Classroom (Case-2) is:

- $\mathrm{P}=61.1 \% ; \mathrm{Cf}=8.9 \% ; \mathrm{VCf}=8.9 \%$; then $(\mathrm{P}+\mathrm{Cf}+\mathrm{VCf})=78.9 \%$

- $\quad$ Referring to Eq. (2), the result of Daylight Comfort Probability (i-DCP) in Case-2 is "PREFERRED".

Table 8. Statistical Analysis of Student Visual Comfort Data in the Classroom (Case-3)

\begin{tabular}{|c|c|c|c|c|c|c|c|c|c|c|c|}
\hline & \multirow{2}{*}{$\begin{array}{l}\text { Classroom } \\
\text { Code }\end{array}$} & \multicolumn{3}{|c|}{ Daylight Intensity (Lux) } & \multirow{2}{*}{ Orientation } & I & \multirow[t]{2}{*}{ D } & \multirow[t]{2}{*}{$\mathrm{P}$} & \multirow{2}{*}{$\frac{\mathrm{Cf}}{4}$} & \multirow{2}{*}{$\frac{\mathrm{VCf}}{5}$} & \multirow{2}{*}{$\begin{array}{l}\text { Sum } \\
(\%)\end{array}$} \\
\hline & & $\min$ & $\max$ & mean & & 1 & & & & & \\
\hline DU & \multirow{3}{*}{ 29-II } & \multirow{3}{*}{112} & \multirow{3}{*}{145} & \multirow{3}{*}{131} & \multirow{3}{*}{$\mathrm{N} / \mathrm{S}$} & 0.0 & 37.1 & 54.3 & 8.6 & 0.0 & 100 \\
\hline $\mathrm{SC}$ & & & & & & 8.6 & 8.6 & 74.2 & 8.6 & 0.0 & 100 \\
\hline GP & & & & & & 22.9 & 34.3 & 17.1 & 8.6 & 17.1 & 100 \\
\hline & & \multicolumn{4}{|c|}{ Average (\%) } & 10.5 & 26.7 & 48.5 & 8.6 & 5.7 & 100 \\
\hline
\end{tabular}

Based on the data in Table 7, the assessment Daylight Comfort of Classroom (Case-3) is:

- $\mathrm{P}=48.5 \% ; \mathrm{Cf}=8.6 \% ; \mathrm{VCf}=5.7 \%$; then $(\mathrm{P}+\mathrm{Cf}+\mathrm{VCf})=62.8 \%$

- $\quad$ Referring to Eq. (1), the result of Daylight Comfort Probability (i-DCP) in Case-3 is "ACCEPTABLE".

Table 9. Statistical Analysis of Student Visual Comfort Data in the Classroom (Case-4)

\begin{tabular}{|c|c|c|c|c|c|c|c|c|c|c|c|}
\hline & \multirow{2}{*}{$\begin{array}{l}\text { Classroom } \\
\text { Code }\end{array}$} & \multicolumn{3}{|c|}{ Daylight Intensity (Lux) } & \multirow{2}{*}{ Orientation } & I & \multirow[t]{2}{*}{$\mathrm{D}$} & \multirow{2}{*}{$\frac{P}{3}$} & \multirow{2}{*}{$\frac{\mathrm{Cf}}{4}$} & \multirow{2}{*}{$\frac{\mathrm{VCf}}{5}$} & \multirow{2}{*}{$\begin{array}{l}\text { Sum } \\
(\%)\end{array}$} \\
\hline & & $\min$ & $\max$ & mean & & 1 & & & & & \\
\hline DU & \multirow{3}{*}{ 10-I } & \multirow{3}{*}{289} & \multirow{3}{*}{335} & \multirow{3}{*}{318} & \multirow{3}{*}{$\mathrm{N} / \mathrm{S}$} & 3.0 & 3.0 & 48.5 & 36.4 & 9.1 & 100 \\
\hline $\mathrm{SC}$ & & & & & & 0.0 & 12.1 & 60.6 & 27.3 & 0.0 & 100 \\
\hline GP & & & & & & 36.4 & 42.4 & 9.1 & 12.1 & 0.0 & 100 \\
\hline \multicolumn{6}{|c|}{ Average $(\%)$} & 13.1 & 19.2 & 39.4 & 25.3 & 3.0 & 100 \\
\hline
\end{tabular}

Based on the data in Table 8, the assessment of Daylight Comfort of Classroom (Case-4) is:

- $\quad \mathrm{P}=39.4 \% ; \mathrm{Cf}=25.3 \% ; \mathrm{VCf}=3.0 \%$; then $(\mathrm{P}+\mathrm{Cf}+\mathrm{VCf})=67.7 \%$

- $\quad$ Referring to Eq. (1), the result of Daylight Comfort Probability (i-DCP) in Case-4 is "ACCEPTABLE". 
Table 10. Statistical Analysis of Student Visual Comfort Data in the Classroom (Case-5)

\begin{tabular}{|c|c|c|c|c|c|c|c|c|c|c|c|}
\hline & \multirow{2}{*}{$\begin{array}{l}\text { Classroom } \\
\text { Code }\end{array}$} & \multicolumn{3}{|c|}{ Daylight Intensity (Lux) } & \multirow{2}{*}{ Orientation } & I & \multirow[t]{2}{*}{$\mathrm{D}$} & \multirow{2}{*}{$\frac{P}{3}$} & \multirow{2}{*}{$\frac{\mathrm{Cf}}{4}$} & \multirow{2}{*}{$\frac{\mathrm{VCf}}{5}$} & \multirow{2}{*}{$\begin{array}{l}\text { Sum } \\
(\%)\end{array}$} \\
\hline & & $\min$ & $\max$ & mean & & 1 & & & & & \\
\hline DU & \multirow{3}{*}{ UP-III } & \multirow{3}{*}{82} & \multirow{3}{*}{175} & \multirow{3}{*}{119} & \multirow{3}{*}{$\mathrm{E} / \mathrm{W}$} & 0.0 & 24.1 & 75.9 & 0.0 & 0.0 & 100 \\
\hline SC & & & & & & 0.0 & 69.0 & 20.7 & 10.3 & 0.0 & 100 \\
\hline GP & & & & & & 0.0 & 96.6 & 3.4 & 0.0 & 0.0 & 100 \\
\hline \multicolumn{6}{|c|}{ Average (\%) } & 0.0 & 63.2 & 33.3 & 3.4 & 0.0 & 100 \\
\hline
\end{tabular}

Based on the data in Table 10, the assessment Daylight Comfort of Classroom (Case-5) is:

- $\quad \mathrm{P}=33.3 \% ; \mathrm{Cf}=3.4 \% ; \mathrm{VCf}=0 \%$; then $(\mathrm{P}+\mathrm{Cf}+\mathrm{VCf})=36.8 \%$

- The result of Daylight Comfort Probability (i-DCP) in Case-5 does not meet either category.

Table 11. Statistical Analysis of Student Visual Comfort Data in the Classroom (Case-6)

\begin{tabular}{|c|c|c|c|c|c|c|c|c|c|c|c|}
\hline & \multirow{2}{*}{$\begin{array}{l}\text { Classroom } \\
\text { Code }\end{array}$} & \multicolumn{3}{|c|}{ Daylight Intensity (Lux) } & \multirow{2}{*}{ Orientation } & I & \multirow{2}{*}{$\begin{array}{c}\mathrm{D} \\
2.0\end{array}$} & \multirow{2}{*}{$\frac{\mathrm{P}}{3.0}$} & \multirow{2}{*}{$\frac{\mathrm{Cf}}{4.0}$} & \multirow{2}{*}{$\frac{\mathrm{VCf}}{5.0}$} & \multirow{2}{*}{$\begin{array}{l}\text { Sum } \\
(\%)\end{array}$} \\
\hline & & $\min$ & $\max$ & mean & & 1.0 & & & & & \\
\hline DU & \multirow{3}{*}{ 29-III } & \multirow{3}{*}{44} & \multirow{3}{*}{58} & \multirow{3}{*}{49} & \multirow{3}{*}{$\mathrm{N} / \mathrm{S}$} & 0.0 & 48.6 & 51.4 & 0.0 & 0.0 & 100 \\
\hline $\mathrm{SC}$ & & & & & & 25.7 & 14.3 & 60.0 & 0.0 & 0.0 & 100 \\
\hline GP & & & & & & 11.4 & 57.1 & 8.6 & 22.9 & 0.0 & 100 \\
\hline \multicolumn{6}{|c|}{ Average (\%) } & 12.4 & 40.0 & 40.0 & 7.6 & 0.0 & 100 \\
\hline
\end{tabular}

Based on the data in Table 8, the assessment of Daylight Comfort of Classroom (Case-6) is:

- $\mathrm{P}=40 \% ; \mathrm{Cf}=7.6 \% ; \mathrm{VCf}=0 \%$; then $(\mathrm{P}+\mathrm{Cf}+\mathrm{VCf})=47.6 \%$

- The result of Daylight Comfort Probability (i-DCP) in Case-6 does not meet either category.

Table 12. Assessment of Daylight Comfort in Classroom (All Cases)

\begin{tabular}{|c|c|c|c|c|c|c|c|}
\hline \multirow{2}{*}{$\begin{array}{l}\text { CLASS } \\
\text { CODE }\end{array}$} & \multirow{2}{*}{ Orientation } & \multicolumn{3}{|c|}{ Daylight Intensity (Lux) } & \multirow{2}{*}{$(\mathrm{P}+\mathrm{Cf}+\mathrm{VCf})$} & \multirow{2}{*}{ SNI } & \multirow{2}{*}{ sDA Perception } \\
\hline & & Min & Max & Avg & & & \\
\hline UP-I & $\mathrm{E} / \mathrm{W}$ & 113 & 371 & 261 & $80.0 \%$ & Comply & Preferred \\
\hline UP-II & $\mathrm{E} / \mathrm{W}$ & 113 & 131 & 153 & $89.3 \%$ & Not Comply & Preferred \\
\hline UP-III & $\mathrm{E} / \mathrm{W}$ & 82 & 175 & 119 & $36.8 \%$ & Not Comply & Not Acceptable \\
\hline ID-I & $\mathrm{E} / \mathrm{W}$ & 101 & 127 & 108 & $63.3 \%$ & Not Comply & Acceptable \\
\hline ID-II & $\mathrm{E} / \mathrm{W}$ & 52 & 70 & 61 & $46.9 \%$ & Not Comply & Not Acceptable \\
\hline ID-IIII & E/W & 277 & 367 & 339 & $88.0 \%$ & Comply & Preferred \\
\hline ID-IV & E/W & 248 & 269 & 260 & $58.3 \%$ & Comply & Acceptable \\
\hline $29-\mathrm{I}$ & $\mathrm{E} / \mathrm{W}$ & 136 & 150 & 143 & $78.9 \%$ & Not Comply & Preferred \\
\hline 29-II & $\mathrm{N} / \mathrm{S}$ & 112 & 145 & 131 & $62.8 \%$ & Not Comply & Acceptable \\
\hline 29-III & $\mathrm{N} / \mathrm{S}$ & 44 & 58 & 49 & $47.6 \%$ & Not Comply & Not Acceptable \\
\hline 29-IV & $\mathrm{N} / \mathrm{S}$ & 121 & 145 & 138 & $77.1 \%$ & Not Comply & Preferred \\
\hline $10-\mathrm{I}$ & $\mathrm{N} / \mathrm{S}$ & 289 & 335 & 318 & $67.7 \%$ & Comply & Acceptable \\
\hline $10-\mathrm{II}$ & $\mathrm{N} / \mathrm{S}$ & 21 & 26 & 24 & $43.8 \%$ & Not Comply & Not Acceptable \\
\hline 10-III & E/W & 136 & 147 & 141 & $83.3 \%$ & Not Comply & Preferred \\
\hline 04-I & $\mathrm{E} / \mathrm{W}$ & 186 & 227 & 206 & $70.5 \%$ & Not Comply & Preferred \\
\hline 04-II & $\mathrm{E} / \mathrm{W}$ & 236 & 274 & 254 & $73.6 \%$ & Comply & Preferred \\
\hline 04-III & $\mathrm{N} / \mathrm{S}$ & 195 & 229 & 209 & $77.1 \%$ & Not Comply & Preferred \\
\hline 04-IV & $\mathrm{N} / \mathrm{S}$ & 185 & 212 & 202 & $90.3 \%$ & Not Comply & Preferred \\
\hline $04-\mathrm{V}$ & $\mathrm{N} / \mathrm{S}$ & 449 & 556 & 503 & $68.3 \%$ & Comply & Acceptable \\
\hline 02-I & $\mathrm{N} / \mathrm{S}$ & 80 & 174 & 148 & $63.7 \%$ & Not Comply & Acceptable \\
\hline 02-II & $\mathrm{N} / \mathrm{S}$ & 19 & 27 & 22 & $46.1 \%$ & Not Comply & Not Acceptable \\
\hline 02-III & $\mathrm{E} / \mathrm{W}$ & 25 & 36 & 29 & $47.6 \%$ & Not Comply & Not Acceptable \\
\hline 21-I & E/W & 123 & 147 & 131 & $82.8 \%$ & Not Comply & Preferred \\
\hline 21-II & $\mathrm{E} / \mathrm{W}$ & 224 & 264 & 243 & $82.8 \%$ & Not Comply & Preferred \\
\hline 21-III & $\mathrm{E} / \mathrm{W}$ & 250 & 359 & 286 & $74.2 \%$ & Comply & Acceptable \\
\hline
\end{tabular}


The method is carried out on the 25 classes that are the object of this research. The results show that there are 12 classes with daylight comfort perceived as "Preferred", there are 7 classes with daylight comfort perceived as "Acceptable", and 6 classes with daylight comfort perceived as "Not Acceptable" and "Not Preferred" (see Table 12).

\section{Discussion}

From the stated results, we can see that there are 12 cases with daylight comfort probability categorized as "Preferred" and there are 7 classes with daylight comfort probability categorized as "Acceptable". We can also see from Table 12 that there are 6 classes that do not fit into either category. From the measurement of natural light intensity in the classroom, the results show that as many as 18 classes do not comply with the minimum lighting value standard by SNI, and only 7 classes comply with the standard (see Table 12).

From field observations, some classrooms did not comply with standards because they did not have good access to natural light. Their daylight access is impeded by vegetation, such as large trees that are placed very close to buildings. In addition, another problem is the limited land owned by the school, which causes the buildings to have to be too close together, especially if the school is located in the middle of a densely populated settlement. From the results, it can be seen that there are 12 classrooms do not meet the requirements recommended by SNI, but the results of the Daylight Comfort Probability (i-DCP) assessment for these 12 rooms are categorized as "Preferred" and "Acceptable". Students still feel that the natural light in the class is comfortable and accept the situation. The SNI method that determines the recommended light intensity is one of the factors that affects visual comfort, which is related to the quantity of light. However, it is not only the quantity of light that affects visual comfort, but also the distribution of light, and the presence or absence of glare that occurs in space and other influencing factors. According to Allan et al. [45], subjective evaluation is important, in addition to evaluation of Daylight Performance Metrics (DPMs), because only doing photometric actions alone does not fully capture the subjective component of lighting.

\section{Conclusions}

Research on students' visual comfort assessment in classrooms and assessments of daylight comfort in classrooms based on students' perceptions have been carried out. This research shows that visual comfort is not influenced by only one factor. An assessment by measuring the intensity of the room's light has not been able to predict accurately whether the space is comfortable or not. This research proposed an alternative approach method for assessing the visual comfort of classrooms with daylight based on students' perception. To the best of the author's knowledge, there has been no previous research using students' perceptions to assess the visual comfort of a classroom. This study shows that, to create visual comfort in classrooms, the factor of uniformity of light, sunlight exposure, and glare must be of particular concern, in addition to the daylight intensity. Visual comfort in the classroom will be created by considering these factors together.

Based on SNI, a good classroom has an average light intensity equal to or above 250 Lux. And, based on this research, it can be proved that classrooms that meet SNI standard are categorized as "acceptable" or "preferred" by the proposed method; however classrooms where light intensity is below 250 Lux are not necessarily categorized as "not acceptable" because of other influencing factors. The daylight uniformity factor is photometrically influenced by the ratio between the minimum and maximum illuminance. Glare and sunlight exposure factors are photometrically influenced by the position of the building, openings, configuration of the aperture model, location, and time.

This method is very simple and easy to use for designers to find out the visual comfort in a room with daylight. Even so, this method certainly still has limitations and requires refinement. Repetitive data collection should be done to obtain more accurate results. In addition to classrooms, it is also possible to apply this method to other room functions. In the future, the authors propose assessing the daylight comfort of a room by using this method for other functions that also require good visual comforts, such as work spaces, libraries, laboratories, or drawing studios. This research opens the opportunity to find a model that can be a reference for a classroom design in the tropics. The model must be able to meet the three elements of comfort, namely uniformity, sunlight comfort, and glare comfort.

\section{Acknowledgments}

We would like to thank the Makassar City Government and the South Sulawesi Provincial Government for their permission to collect data at the school that was used as the research sample. We also want to thank all the college students of the Architecture Department of Muhammadiyah University Makassar for their contribution to data collection and surveys.

\section{REFERENCES}

[1] P. R. Boyce, Human factors in lighting. Second Edition (2nd ed.): Crc Press, 2014. 
[2] R. Leslie, Capturing the daylight dividend in buildings: why and how?, Building environment, Vol. 38, No. 2, pp. 381-385, 2003.

[3] US-DOE, Commercial buildings energy consumption survey (CBECS). 2006.

[4] US-EIA, "Energy information administration, official energy statistics from the US government," ed, 2008.

[5] K. M. Van Den Wymelenberg, Christopher, Simulation-based Daylighting Design Education and Technical Support, Sydney, 2011.

[6] Baharuddin, T. Ishak, Analisis Ketersedian Radiasi Matahari di Makassar, Faculty of Engineering Research Prosiding, Makassar, Vol. 6, 2012.

[7] R. Rahim, S. Lau, B. Hamzah, R. Hidayah, Daylight Measurement Data in Makassar-Indonesia, 11th International Conference on Sustainable Environmental Architecture (SENVAR), 2010.

[8] Baharuddin, S. S. Lau, R. Rahim, Daylight availability in Hong Kong: classification into three sky conditions, Architectural Science Review, Vol. 53, No. 4, pp. 396-407, 2010 .

[9] I. Edmonds, P. Greenup, Daylighting in the tropics, Solar energy, Vol. 73, No. 2, pp. 111-121, 2002.

[10] P. Plympton, S. Conway, K. Epstein, Daylighting in Schools: Improving Student Performance and Health at a Price Schools Can Afford, pp. 487-492, 2000.

[11] W. Wu, E. Ng, A review of the development of daylighting in schools, Lighting research technology, Vol. 35, No. 2, pp. 111-124, 2003.

[12] S. Mirrahimi, N. L. N. Ibrahim, M. Surat, Effect of daylighting on student health and performance, Proceedings of the 15th International Conference on Mathematical and Computational Methods in Science and Engineering, Kuala Lumpur, Malaysia, pp. 2-4, 2013.

[13] L. Heschong, Day lighting and student performance, ASHRAE, Vol. 44, pp. 65-67, 2002.

[14] R. Küller, S. Ballal, T. Laike, B. Mikellides, G. Tonello, The impact of light and colour on psychological mood: a cross-cultural study of indoor work environments, Ergonomics, Vol. 49, No. 14, pp. 1496-1507, 2006.

[15] E. Lam, A. Chan, D. Chan, Active Learning Strategies for Building Engineering Students for Sustainable Knowledge Development, Civil Engineering Architecture, Vol. 3, No. 5, 2015.

[16] V. De Giuli, O. Da Pos, M. De Carli, Indoor environmental quality and pupil perception in Italian primary schools, Building Environment, Vol. 56, pp. 335-345, 2012.

[17] S. Latif, B. Hamzah, R. Rahim, R. Mulyadi, A. E. E. Putra, STUDY OF THE HEAT VENTILATION WITH INCLINED CHIMNEY IN THE ATTIC, International Journal of GEOMATE, Vol. 17, No. 64, pp. 178-184, 2019.

[18] S. Sufar, A. Talib, H. Hambali, Towards a better design: physical interior environments of public libraries in peninsular Malaysia, Procedia-Social Behavioral Sciences, Vol. 42, pp. 131-143, 2012.
[19] S. Carlucci, F. Causone, F. De Rosa, L. Pagliano, A review of indices for assessing visual comfort with a view to their use in optimization processes to support building integrated design, Renewable and Sustainable Energy Reviews, Vol. 47, pp. 1016-1033, 2015.

[20] T. A. Shamaki, Practice, Influence of Learning Environment on Students' Academic Achievement in Mathematics: A Case Study of Some Selected Secondary Schools in Yobe State-Nigeria, Journal of Education, Vol. 6, No. 34, pp. 40-44, 2015.

[21] M. Luckiesh, S. Guth, Brightness in visual field at borderline between comfort and discomfort, Journal Illuminating engineering, Vol. 44, pp. 650-670, 1949.

[22] R. G. Hopkinson, Glare from daylighting in buildings, Applied ergonomics, Vol. 3, No. 4, pp. 206-215, 1972.

[23] H. Einhorn, Discomfort glare: a formula to bridge differences, Lighting Research Technology, Vol. 11, No. 2, pp. 90-94, 1979.

[24] TC3-13, Discomfort glare in interior lighting. CIE Publication 117, Vienna: CIE., 1995.

[25] A. Nazzal, A new daylight glare evaluation method: Introduction of the monitoring protocol and calculation method, Energy Buildings, Vol. 33, No. 3, pp. 257-265, 2001.

[26] R. Harrold, D. Mennie, IESNA Lighting Ready Reference: A Compendium of Materials from The IESNA Lighting Handbook: Lighting Fundamentals, Vision and Color, Light Sources, Illuminance Selection and Design Guide, Calculation Data and Design Guide, Energy Management Considerations, Lighting Economics, Definitions. Illuminating Engineering Society of North America, 2003.

[27] J. Wienold, J. Christoffersen, Evaluation methods and development of a new glare prediction model for daylight environments with the use of CCD cameras, Energy buildings, Vol. 38, No. 7, pp. 743-757, 2006.

[28] M. B. Hirning, G. L. Isoardi, V. R. Garcia-Hansen, Prediction of discomfort glare from windows under tropical skies, Building Environment, Vol. 113, pp. 107-120, 2017.

[29] L. Giovannini, F. Favoino, V. R. Lo Verso, A. Pellegrino, V. Serra, A simplified approach for the annual and spatial evaluation of the comfort classes of daylight glare using vertical illuminances, Buildings, Vol. 8, No. 12, p. 171, 2018.

[30] G. Chinazzo, J. Wienold, M. J. L. R. Andersen, Influence of indoor temperature and daylight illuminance on visual perception, Lighting Research Technology, Vol. 52, No. 3, pp. $350-370,2020$.

[31] S. S. Korsavi, Z. S. Zomorodian, M. Tahsildoost, Visual comfort assessment of daylit and sunlit areas: A longitudinal field survey in classrooms in Kashan, Iran, Energy Buildings, Vol. 128, pp. 305-318, 2016.

[32] C. F. Reinhart, D. A. Weissman, The daylit area-Correlating architectural student assessments with current and emerging daylight availability metrics, Building environment, Vol. 50, pp. 155-164, 2012.

[33] M. Jamnický, Building information modeling with static and dynamic daylight analysis, Advanced Materials Research, 
Vol. 855, pp. 255-258, 2014.

[34] M. Piderit, B. María, C. Y. Labarca, Methodology for assessing daylighting design strategies in classroom with a climate-based method, Sustainability, Vol. 7, No. 1, pp. 880-897, 2015.

[35] C. F. Reinhart, J. Mardaljevic, Z. Rogers, Dynamic daylight performance metrics for sustainable building design, Leukos, Vol. 3, No. 1, pp. 7-31, 2006.

[36] J. Mardaljevic, L. Heschong, E. Lee, Daylight metrics and energy savings, Lighting Research Technology, Vol. 41, No. 3, pp. 261-283, 2009.

[37] A. Tsagrassoulis, A. Kontadakis, A. Roetzel, Comparing climate based daylight modelling with daylight factor assessment-implications for architects, ASA2015: Living and learning: research for a better built environment: Proceedings of the 49th International conference of the Architectural Science Association, pp. 1097-1106, 2015.

[38] Ö. Erlendsson, Daylight Optimization-A Parametric Study of Atrium Design: Early Stage Design Guidelines of Atria for Optimization of Daylight Autonomy. 2014.

[39] J. A. Jakubiec, The use of visual comfort metrics in the design of daylit spaces. Massachusetts Institute of Technology, 2014.
[40] A. M. Atzeri, F. Cappelletti, A. Gasparella, H. Shen, A. Tzempelikos, Assessment Of Long-Term Visual And Thermal Comfort And Energy Performance In Open-Space Offices With Different Shading Devices, 3rd International High Performance Buildings Conference at Purdue, pp. 1-10, 2014.

[41] S. Latif, B. Hamzah, M. Rahim, R. Mulyadi, I. Idrus, Thermal investigation on the attics of buginese traditional houses in South Sulawesi, IOP Conf. Series: Earth and Env. Sci., Vol. 382, No. 1, p. 012024, 2019.

[42] B. S. Nasional, SNI 03-2396-2001: Tata cara perancangan sistem pencahayaan alami pada bangunan gedung (Procedures for Designing Natural Lighting Systems in Buildings). Jakarta, 2001.

[43] N. Jamala, R. Rahim, S. Latief, H. Ramli, Light Distribution Analysis on Buildings Located on the Coastal, IOP Conf. Series: Mat. Sci. and Eng., Vol. 676, No. 1, p. 012036, 2019.

[44] I. Idrus, M. R. Rahim, B. Hamzah, N. Jamala, Daylight intensity analysis of secondary school buildings for environmental development, IOP Conf. Series: Earth and Environ. Sci., Vol. 382, No. 1, p. 012022, 2019.

[45] A. C. Allan, V. Garcia-Hansen, G. Isoardi, S. S. Smith, Subjective assessments of lighting quality: A measurement review, Leukos, Vol. 15, No. 2-3, pp. 115-126, 2019. 